\title{
Imprensa periódica ilustrada e política: a revista Kodak e a palheta republicana Porto Alegre (1912-1913)
}

Alice Dubina Trusz ${ }^{1}$

\section{Resumo}

Na década de 1910, foi publicada em Porto Alegre/RS a revista Ko$d a k$, um semanário ilustrado dedicado às artes e à literatura, em cujas páginas estariam ausentes as 'cores políticas'. Tal determinação editorial acabou contrariada, pois foram numerosas as referências textuais e visuais à política na revista. 0 objetivo deste estudo é identificar as manifestações desta natureza no primeiro semestre da publicação, indagar os usos e funções que elas podem ter desempenhado e o papel que podem ter conferido à Kodak naquele contexto. Palavras-chave: Imprensa periódica ilustrada, política, revista Kodak, humor

\section{Illustrated periodical press and politics: Kodak magazine and the republican color palette Porto Alegre (1912-1913)}

\section{Abstract}

In the 1910s, in Porto Alegre/RS the Kodak magazine was published - an illustrated weekly magazine dedicated to the arts and literature, whose pages were missing the 'political color'. This editorial determination was ultimately overturned, as there were numerous textual and visual references to politics in the magazine. The aim of this study is to identify such occurrences in the first semester of the publication, to investigate the uses and functions that they may have played and the role that can be given to Kodak in that context.

Key-words: Illustrated periodical press, politics, Kodak magazine, humor

${ }^{1}$ Doutora em História. Email: alicedtrusz@gmail.com 
A revista Kodak foi publicada em Porto Alegre, capital do Rio Grande do Sul, entre 1912 e 1923, mas com duas interrupções e também diferentes equipes produtoras e perfis editoriais. Tratava-se de uma revista semanal ilustrada dedicada às artes e à literatura, em cujo editorial de lançamento assinalou-se que as 'cores políticas' não se fariam presentes em suas páginas. Contrariando tal determinação, foram numerosas as referências textuais e visuais à política na Kodak, contemplando os âmbitos local, estadual, nacional e mesmo internacional. 0 objetivo deste estudo é identificar as manifestações desta natureza no primeiro semestre da publicação, indagando os usos e funções que podem ter desempenhado e o papel que podem ter conferido à revista no seu contexto de circulação. Assim, serão examinadas as edições publicadas entre setembro de 1912 e maio de 1913, período durante o qual as suas capas foram abertamente espaços de veiculação de comentários críticos sobre política por meio de charges. Entre as edições de n. 1 a 36, lançadas entre 28/09/1912 e 21/06/1913, quatorze charges e duas caricaturas com temática política ocuparam tal espaço.

A partir da análise dos conteúdos dessas edições, cotejados a informações fornecidas pela imprensa diária, pretende-se evidenciar as redes de relações políticas nas quais esteve inscrita a Kodak e que, se não participaram diretamente de sua viabilização material, influenciaram sua orientação editorial e, dessa forma, a qualificaram a circular e ser bem recebida entre a elite política e econômica local, responsável pela administração e condução do Estado, bem como entre a elite intelectual, o grupo dos literatos e jornalistas que produziram os órgãos de imprensa da época. Foram essas mesmas elites que constituíram a sua comunidade leitora.

A identificação dos elos entre a imprensa periódica ilustrada e a política na época no Rio Grande do Sul, ou a dificuldade de evitá-los mesmo em uma publicação do gênero da Kodak, uma revista mais voltada ao mundanismo das novas sociabilidades urbanas, 
abre uma nova perspectiva para a compreensão do processo de produção cultural no Brasil da República Velha. Ele foi marcado pela transformação da imprensa, que se aperfeiçoou como indústria e se racionalizou como empresa, e, nesse movimento, estabeleceu e desfez compromissos com as elites, porque elas detinham (e delas obtinham) verbas, formação ou fluidez no poder e na sociedade.

\section{As transformações do jornalismo e surgimento das revistas com fotogravuras}

A relação da imprensa e das revistas ilustradas, em particular, com a política no século XIX foi intensa e marcada por uma crítica incisiva. Ela esteve estreitamente vinculada ao humor e à visualidade, sobretudo à ilustração gráfica, que foi a sua principal via de expressão. Esse caráter politizado e belicoso se transformou na virada do século, em boa parte devido às inovações tecnológicas e aos avanços dos meios de transporte e comunicações, que permitiram a chegada mais rápida, diversificada e atualizada das informações aos jornais, tornando-os mais noticiosos (BROCA, 1958).

A partir de 1900, as revistas ilustradas humorísticas, que predominaram no século anterior, ganhariam a companhia de revistas literárias e artísticas, de costumes e variedades. Elas proliferaram no Brasil como expressões mais apuradas de uma imprensa em processo de renovação geral, interessada em transitar entre o local e o universal, abrindo-se às novas tendências comportamentais. Dessa forma, respondiam ao desejo de cosmopolitismo da parcela da população mais informada e de maior poder aquisitivo, que seria o seu público leitor. A diversidade temática dessas publicações lhes permitiu uma aproximação ampla das mudanças que transfiguravam os espaços das cidades e das novas práticas sociais neles empreendidas. Tal característica pode ser observada nas suas crônicas, colunas sociais e anúncios, mas a 
melhor tradução formal e artística da sua integração ao espírito mundano da época foi o largo emprego que fizeram das ilustrações de humor e da fotografia.

Produtos dos aperfeiçoamentos da indústria gráfica, que permitiram aos jornais novos formatos e maiores tiragens, as revistas também se beneficiaram da substituição das técnicas de impressão litográfica (utilizadas pelas revistas brasileiras desde a década de 1860) pela fotogravura, autotipia e outros processos de reprodução de imagens na imprensa, o que permitirá que em 1900 seja publicada no Rio de Janeiro a primeira revista contendo fotografias como parte substancial de seus conteúdos: a Revista da Semana, lançada como edição ilustrada do Jornal do Brasil.

Tais mudanças, que inscreveram a imprensa no processo de proliferação das imagens técnicas no cotidiano, dinamizado pelo cinema desde 1895, também incidiram sobre a qualidade dos conteúdos e as formas de tratá-los. Tanto a imprensa diária como a periódica passaram a demonstrar interesse crescente pela vida cotidiana, as deficiências estruturais e os progressos urbanísticos das capitais, os problemas sociais e as mudanças comportamentais e culturais dos cidadãos republicanos. Tais temas seriam abordados de forma distinta por cada gênero jornalístico, de acordo com sua natureza e possibilidades.

\section{A imprensa periódica ilustrada em Porto Alegre}

Embora a Kodak tenha sido um marco no seu gênero de publicação, inaugurando uma nova fase na imprensa periódica local (TRUSZ, 2002), foi produto de uma longa tradição histórica de publicação de revistas ilustradas. Como no Rio de Janeiro, também em Porto Alegre, a década de 1860 viu surgirem os semanários ilustrados críticos e humorísticos, dentre os quais merecem destaque a pioneira A Sentinella do Sul (1867-1869), O Fígaro (1878), ambos de crítica moderada, e O Século (1880-1892), 
que foi o periódico humorístico de maior tiragem e circulação do Estado devido às críticas contundentes que fez aos liberais, aos conservadores e à igreja, aproveitando a inexistência de censura e prisões durante a Monarquia. Já os republicanos foram responsáveis pela prisão do seu diretor e pela proibição da publicação da folha, que sofreu várias interrupções até desaparecer (FERREIRA, 1962).

As publicações periódicas ilustradas porto-alegrenses das primeiras décadas do século XX apresentariam um perfil bastante diverso das antecessoras, que foi se modificando lentamente, de acordo com os avanços técnicos e intelectuais locais. Tal renovação também foi estimulada pelas publicações cariocas, comercializadas na cidade desde o final do século XIX. Em 1899, por exemplo, revistas ilustradas de modas e atualidades, como A Estação e A Revista Moderna, estavam à venda nas livrarias porto-alegrenses. Em 1901, também se tinha acesso à revista portenha Caras y Caretas, que reproduzia charges, caricaturas e fotografias de países europeus, da Argentina e mesmo do Brasil. A sua edição de maio deste ano continha uma reportagem fotográfica especial sobre a Exposição Estadual realizada em Porto Alegre. A Revista da Semana, do Rio, também estava à venda na Livraria do Globo neste momento, trazendo um dossiê fotográfico sobre o mesmo evento. Em 1904, está disponível a revista ilustrada carioca Kosmos. Em 1907, a revista Renascença. ${ }^{2}$ Em julho, também ela lançou uma edição especial dedicada ao Rio Grande do Sul, demonstrando haver entre as revistas cariocas uma preocupação em conquistar os mercados regionais - daí as edições temáticas - e um reconhecimento da importância do meio leitor porto-alegrense e gaúcho e do seu interesse por este gênero de publicação.

${ }^{2}$ Surgiu em março de 1904, no Rio de Janeiro, tendo como diretores Rodrigo Octavio e Henrique Bernardelli. 
A partir de 1908, estão disponíveis nas livrarias porto-alegrenses as revistas ilustradas cariocas Careta e $O$ Malho. ${ }^{3}$ A partir de agosto junta-se a elas a Degas, recém lançada. Em setembro, a revista infantil Tico-Tico, publicada pela empresa d' O Malho desde 1905. Em julho de 1909, está à venda a revista Leitura para todos e, em outubro, a Fon-Fon, ambas produzidas no Rio de Janeiro, a última desde 1907. Em janeiro de 1910, ingressa no mercado local outra publicação d' O Malho, a Illustração Brasileira. Em 1912, além das citadas revistas nacionais, são vendidas na capital gaúcha revistas estrangeiras provenientes de países como Alemanha, França, Itália, Portugal e Espanha.

No que respeita às publicações locais, observa-se já no início do século XX o surgimento de revistas literárias, algumas de maior duração, como $O$ Escrínio, de 1901, e outras de vida curta, como a Via Láctea (1906), O Mimo (1909) e Alma (1910). Destacam-se, porém, as revistas humorísticas, que de certa forma deram continuidade à tradição da imprensa caricata do século XIX. Veiculando apenas texto e ilustrações (charges e caricaturas), foram publicados desde 1905 semanários como Pau-Bate (1905-1910), O Cavador (1907), Anzol (1907), Não Pode (1908-1910), O Cáustico (1909), Maria Conga, A Rua e D. Quixote (1910) e 606 (19101913?). 0606 e o Pau-Bate distinguem-se pela sua duradoura publicação e também por terem sido ilustrados e dirigidos por Orzolino Martins, o Nero, que será uma dos mais importantes ilustradores da Kodak.

Dentre os periódicos contendo reproduções fotográficas, publicados em Porto Alegre antes da Kodak, acredita-se ter sido a Revista do Sul a pioneira na exploração, ainda que tímida, da

3 O Malho surgiu em setembro de 1902 e foi fundada por Luís Bartolomeu de Souza e Silva. Este semanário foi a primeira publicação brasileira a substituir a pedra litográfica por placa de zinco. A Careta foi lançada em junho de 1908 pelo jornalista e empresário Jorge Schmidt, que exerceu a sua direção entre 1908 e 1935. Ele havia fundado, em 1904, a revista Kosmos. 0 principal caricaturista da Careta foi J. Carlos, que a ilustrou com exclusividade entre 1908 e 1921. Desde 1902, ele também ilustrava O Malho. 
nova orientação temática e estética que começava a orientar o periodismo brasileiro. Lançada em outubro de 1904, como "semanário literário e artístico", com capa impressa em cores, a $R e$ vista do Sul teve por proprietário e diretor o desenhista e pintor Carlos Reis, "correligionário" do jornal A Federação, ou seja, republicano praticante. Essa sua opção política ficou evidente nos conteúdos da revista, por meio da publicação de retratos de Borges de Medeiros, então presidente do Estado e chefe do Partido Republicano Rio-Grandense (PRR), e de Júlio de Castilhos, líder político e idealizador da doutrina positivista, que orientou os republicanos gaúchos, seu partido e sua primeira Constituição, por ele elaborada em 1891 e um dos mecanismos fundamentais da manutenção de seus representantes no poder estadual durante a República Velha (TRINDADE, 1979). A 4⿳a edição da revista, por exemplo, publicada em 22/10, dois dias antes do $1^{\circ}$ aniversário de morte de Castilhos, foi dedicada ao "Grande Morto"; na edição seguinte, foram publicadas as fotografias do extenso préstito realizado até o seu túmulo naquela ocasião, em saudação de sua memória. No final de 1905, ela lançou um álbum fotográfico impresso com imagens dos dirigentes e políticos republicanos. Em 1906, reaparelhou suas oficinas e qualificou sua qualidade de impressão gráfica e reprodução fotográfica, mantendo-se em circulação em 1907.

Em julho de 1906, foi lançada a Semana Illustrada, dirigida por João Guimarães e Mário Furtado, também "correligionários" d'A Federação. Voltada à literatura e ao humor, ela publicava ilustrações e [foto]gravuras e era impressa pela Livraria do Globo. Como a Revista do Sul, também tingiu suas páginas com as cores da opção política de seus editores. Em agosto, publicou um retrato do intendente (prefeito) José Montaury, indicado pelo PRR em 1896 para administrar a cidade e sucessivamente mantido no cargo, até 1924 (BAKOS, 1996), e de Carlos Barbosa Gonçalves, que disputaria as eleições no ano seguinte como candidato oficial de Borges à presidência do Estado (governo estadual) e as venceria (TRINDADE, 1991). 
Em maio de 1909, foi lançada a "revista humorística e literária" Bico da Chaleira, mais próxima na feitura às revistas ilustradas nacionais comercializadas em Porto Alegre e à futura Kodak, porque prometeu reproduzir, além dos retratos e panoramas fotográficos, "instantâneos locais". Redigida por Luiz Napoleão Lopes, apresentou, em seu número inaugural, "abundante texto, instantâneos de exmas. famílias, trazendo também uma página com os retratos dos protagonistas do crime do Partenon" (A Federação, 22/05/1909, p. 4), demonstrando, assim, atualidade temática e expressiva. Contudo, parece ter tido vida efêmera. Outro exemplo foi A Bigorna, revista "crítica, artística e literária" lançada em junho de 1909 com a promessa de que seguiria os moldes da Careta, do Rio. A sua 1a edição trazia "boas [foto]gravuras e excelente texto, um e outro tratando de assuntos de atualidade".

Distinguiu-se das colegas anteriores a Revista dos Municípios, lançada em junho de 1910. Sua duradoura publicação, que continuava em curso em 1913, se deve, em parte, a ter sido "órgão de propaganda do Estado" e ter surgido com oficinas próprias. De publicação mensal, teve por diretores e proprietários Luiz Coelho da Silva, "correligionário" da Federação, e Nei de Lima Costa. 0 retrato de Carlos Barbosa, então presidente do Estado, ocupou a capa de sua 1a edição. Nas seguintes, trouxe numerosas fotogravuras de municípios do interior gaúcho.

O semanário A Mala foi lançado em fevereiro de 1911 como revista literária e humorística ilustrada, que traria "ilustrações e instantâneos e abordaria assuntos locais", sendo "modelada pelas congêneres do Rio". Era seu diretor, redator e proprietário o acadêmico de direito e "correligionário" d'A Federação Luiz Napoleão Lopes, que havia publicado o Bico da Chaleira. Como tal, homenageou o PRR em sua 1 a edição, reproduzindo "vários instantâneos da chegada do eminente senador Pinhei- 
ro Machado" a Porto Alegre, o seu maior representante a nível nacional. ${ }^{4}$

Em maio de 1911, surgiu o semanário Smart, revista "crítica, humorística e de arte", que deve ter sido a versão local mais bem acabada até então produzida das revistas ilustradas cariocas. Além do "qualificado corpo de colaboradores", não explicitado, foi elogiada por sua "variada matéria artística", a "seção de modas, ilustrada com clichés das mais modernas confecções parisienses" e a intenção de promover concursos infantis instrutivos, tal qual a Fon-Fon. A Smart era impressa "em excelente papel" nas oficinas da Revista dos Municípios e destacou-se pela atualidade técnica e variedade temática das imagens fotográficas que veiculou, de grupos, edificações, panoramas de localidades do interior do Estado, instantâneos de eventos locais, e também pelos seus conteúdos textuais, que cobriram acontecimentos cotidianos como festas esportivas e religiosas, trazendo ainda crônicas, entrevista com o intendente Montaury, seções infantil e esportiva, charges de "crítica à atualidade política" e anedotas.

A revista teve problemas para manter sua publicação regular entre junho e julho de 1911, identificados com a "falta de tipógrafos na cidade". Mas recuperou a regularidade e, em setembro de 1911, reproduziu, em primeira mão, fotogravuras do "crime da rua da Praia”, que chocou a pacata capital gaúcha. Em outubro, publicou fotogravuras da habitual romaria de "Glorificação" à memória de Júlio de Castilhos, com a visita ao cemitério.

Como foi possível observar, que a maior parte das publicações ilustradas acima citadas foi editada por indivíduos inscritos politicamente, na maior parte afiliados ao PRR, que não se furta-

\footnotetext{
${ }^{4}$ A Federação, Porto Alegre, 06/02/1911. Pinheiro Machado foi eleito senador assim que foi proclamada a República. Ele só deixou o Senado para combater na guerra civil de 1893, no RS, ao lado dos republicanos. Após, reassumiu a cadeira no senado, deixando-a apenas em setembro de 1915, quando foi assassinado no Rio de Janeiro.
} 
ram em demonstrar seu compromisso ou relações com o poder constituído nas revistas artísticas, literárias e humorísticas que publicaram, ainda que nenhuma delas fosse órgão político partidário. Com a Kodak não seria diferente.

\section{A revista Kodak}

Dos periódicos acima citados, com exceção de um número do 606, nenhum foi preservado. Já a Kodak foi, levando muitos pesquisadores a acreditarem que tudo começou com ela. ${ }^{5}$ Contudo, se ela não foi a primeira revista ilustrada local, foi, no seu gênero, aquela que apresentou maior duração e profissionalismo, investindo desde cedo na equipe de produção e em oficinas próprias, que permitiram sua qualificação técnica e intelectual, bem como autonomia comercial, viabilizando a afirmação do gênero no meio local e contribuindo para a racionalização empresarial da empresa jornalística. ${ }^{6}$

A primeira fase da Kodak, durante a qual manteve uma periodicidade semanal regular, se estendeu do seu lançamento, em 28/09/1912, até dezembro de 1914. Ela ressurgiu em 21/07/1917, dirigida por Lourival Cunha, seu fundador e pri-

${ }^{5}$ A Kodak tem sido objeto de minhas pesquisas, respondendo a diferentes indagações, desde o início da década de 1990. Há exemplares do periódico nos acervos da Biblioteca Pública do Estado (BPE), do Museu de Comunicação Social Hipólito José da Costa, do Museu Joaquim José Felizardo, do IHGRGS, da PUCRS e da Biblioteca Pública de Rio Grande. Nenhum destes acervos, porém, possui sua coleção completa. Em 2007, a coleção da BPE, que era a mais volumosa, perdeu $70 \%$ das edições que detinha em razão de furto. A maior parte dos dados apresentados neste texto foi levantada em edições da Kodak hoje desaparecidas e certamente em posse de algum colecionador privado.

${ }^{6}$ Nos seus primeiros números, a Kodak foi impressa nas oficinas gráficas da Livraria do Globo. Em meados de dezembro de 1912, ela já mantinha em funcionamento uma oficina de fotogravura e havia adquirido o maquinário necessário para instalar sua própria tipografia, o que foi realizado em fevereiro de 1913. A partir de março, ela passou a oferecer os serviços de suas oficinas de fotogravura no mercado estadual, abrindo um novo canal de recursos para sua própria sustentação. 
meiro diretor-proprietário, mas como produto da Sociedade (em comandita) Jornalística Kodak. Dando continuidade à fase anterior - a sua primeira edição em 1917 foi a n. 1 do ano 3 - a publicação retornou semanal, mas sofreu várias interrupções, sendo encerrada ao final de 1920 já com periodicidade mensal. A Kodak reapareceu em 1923, mas deste ano são conhecidas apenas duas edições, uma publicada em janeiro, pela Cia. de Publicidade Ltda., e a outra em outubro, já sob propriedade e direção de Fernando Barreto e Carlos H. Araújo. Ao longo desta trajetória, a revista contou com diferentes redatores, diretores artísticos, ilustradores e fotógrafos, que lhe conferiram distintas orientações.

O nome com que foi batizada - Kodak - já dava conta da importância e do grande entusiasmo pelas novas tecnologias visuais no contexto dos anos de 1910. A associação das imagens mecânicas com a ideia de progresso fazia com que as revistas, ao fazerem uso da fotografia como nova linguagem e forma de apropriação e expressão da realidade, se mostrassem conformes com as descobertas científicas e a dinâmica do seu tempo, procurando concentrar em si próprias um atributo de modernidade.

Tais aspectos e preocupações ficam evidentes nos textos de caráter editorial publicados pela Kodak nas suas duas primeiras edições. Lançada sem subtítulo, mas referida na imprensa diária como "revista ilustrada local de arte, literatura e elegâncias" ( $O$ Diário, 26/09/1912, p. 4), ela assim se apresentou:

KODAK aparece com a primavera; mas, ao contrário desta, (...), KODAK entra na vida despida de todo atavio, sem título algum de recomendação. (...). O nome com que a batizamos lhe define previamente a feitura e a destinação: ela será a fotografia semanal do Estado e, particularmente, da cidade. Vida intelectual e mundana, vida industrial e artística, vida comercial e esportiva, todas as manifestações de nossa existência moderna, tudo ela registrará com sua objetiva pluriforme e adequada. KODAK será revista de poucas pala- 
vras e de muitas ilustrações; de poucas palavras porque nos elétricos tempos que decorrem, de cinematografia e de vertigem, tudo deve ser breve, instantâneo, sintético, de muitas ilustrações, por que, como instrumento de luta e propaganda, nada há de mais eficaz e eloqüente que a figura geométrica de uma caricatura ou de um cliché. Sendo nosso intuito fazer obra de simpatia, de solidariedade e de aperfeiçoamento social, seja muito embora uma revista impressa a cores, fica, desde já, proscrita de suas colunas toda e qualquer cor política, como perniciosa à vista e ao coração. KODAK concede aos seus colaboradores inteira liberdade artística e filosófica, literária e ortográfica, sem desistir, contudo, do seu elevado propósito, que é o de fazer da Arte, da prosa e do verso uma criteriosa seleção de verdade e de beleza. São estas as nossas credenciais. (Kodak, ano 1, n. 1, 28/09/1912)

Um segundo texto, do mesmo caráter, saiu na $2^{\text {a }}$ edição, dando conta do esgotamento da edição inaugural no mesmo sábado do lançamento. Ao salientar o seu objetivo, "dotar Porto Alegre de uma revista, pelo folhear da qual se possa aferir, mais ou menos, de nosso nível intelectual, elegante e artístico", insistiu-se na sua distância da propaganda política, nos primados da variedade e atualidade dos conteúdos e sua expressão visual, aspectos essenciais da imprensa ilustrada dos novos tempos:

Asseveramos, no artigo inicial, ser nosso intuito fazer uma revista leve, de poucas palavras e de muitas ilustrações. $\boldsymbol{A}$ missão de KODAK não é doutrinar, combater, corrigir: é fotografar. Um aspecto de alma, um aspecto de ocaso, um aspecto de rua, traduzi-los-emos, sempre que nos for dado, com clichés. Escreveremos com placas, não com penas. Temos esperanças de não ser, deste modo, nem prolixos, nem infiéis. E faremos de KODAK um pequeno arquivo de história e de arte, retratando vultos, fixando aspectos, refletindo a vida tal qual é. (Kodak, ano 1, n. 2, 05/10/1912)

Os destaques da autora, em negrito, nas duas citações também parecem evidenciar uma desconfiança em relação ao discurso textual, em oposição a uma crença profunda no caráter docu- 
mental das imagens fotográficas, devida à sua natureza técnica e ao seu forte caráter indiciário, que era, de resto, a concepção então vigente acerca da fotografia no que respeita a sua capacidade de dar da realidade uma visão objetiva.

Ao longo de sua primeira fase de publicação, a Kodak realmente seguiu seus propósitos editoriais no que respeita aos usos das imagens fotográficas como meios de expressão e informação, conferindo-lhe autonomia e não empregando-a como mera ilustração de textos. Ela também cumpriu sua determinação em perseguir "todas as manifestações de nossa existência moderna", verificando-se, inclusive, uma mundanização crescente dos seus conteúdos, via ampliação do espaço dedicado a temas como a mudança dos costumes e o incremento das sociabilidades públicas, estimulados pela afirmação das salas de cinema, sobretudo (TRUSZ, 2012).

Já com relação à política, contrariou suas próprias determinações, mostrando-se multicolorida e mesmo vibrante em algumas ocasiões. Após este período, ela mudaria a palheta de cores, mas não as excluiria de suas páginas. Manifestações dessa ordem podem ser verificadas na revista tanto em conteúdos textuais quanto visuais. Se a Kodak não teve (inicialmente) uma seção política propriamente dita, permitiu que a sua pendência pelo borgismo ficasse explícita nas fotografias que selecionou e publicou, de políticos, militares e empresários vinculados ao governo e ao PRR, nos eventos que seu repórter fotografou, nos comentários dispersos nas crônicas, nas charges veiculadas em suas páginas internas e principalmente naquelas veiculadas nas suas capas. Por meio das representações visuais de situações e personagens reais e imaginários da política local, regional, nacional e internacional, foram abordadas, criticadas ou legitimadas práticas e concepções que orientavam as condutas cotidianas dos seus protagonistas. Nesse sentido, observa-se que a Kodak manteve uma visão crítica das políticas nacional e municipal, mas assumiu posição de adesão e propaganda da política estadual. 


\section{As capas coloridas da Kodak}

As capas da Kodak foram ocupadas por ilustrações desde a edição n. 3 (12/10/1912) até a edição n. 36 (21/06/1913), embora com interrupções. Já no período seguinte, as reproduções fotográficas dominam este espaço nobre, sobretudo os retratos femininos, embora apareçam também panoramas fotográficos, bem como reproduções de pinturas e esculturas. Dentre as 31 capas ilustradas veiculadas até 21/06/1913, 16 fazem referência direta à política. Foram seus ilustradores Giga (9), Nero (5) e Luiz Peixoto (2). Considerando os objetivos deste estudo, serão privilegiadas as charges, que são em número de 14 . As assinadas por Giga começaram a ser publicadas na Kodak n. 5 (26/10/1912) e desapareceram depois da edição n. 22 (15/03/1913). A partir da ed. n. 19 (22/02/1913), o espaço passa a receber charges de Nero. Por alguns números, suas charges (n. 19 e 21) se alternarão às de Giga (n. 20 e 22). Depois que Giga deixa de ilustrar as capas, Nero assina outras cinco edições, mas apenas duas delas são charges de sátira política (n. 24 e 31).

\section{Giga e Nero além dos pseudônimos...}

A inscrição social, principalmente a profissional, dos jornalistas, intelectuais e artistas envolvidos na produção da Kodak tem caráter fundamental para a compreensão da qualidade dos conteúdos da revista, das visões de mundo que veicularam, e para se pensar quais teriam sido as suas motivações e implicações. É com base em tais considerações que serão abordados os envolvidos na produção da Kodak.

Giga era o pseudônimo do artista italiano Giuseppe Gaudenzi. Com formação em desenho, pintura, arquitetura e escultura, era amigo do pintor gaúcho Pedro Weingärtner desde 1895. Foi ele quem o apresentou ao engenheiro João Lüderitz na Itália, em 1909 (CORONA, 1956, p. 157), quando este, professor do Ins- 
tituto Técnico Profissional Benjamin Constant (posteriormente Instituto Parobé) da Escola de Engenharia de Porto Alegre, estava na Europa, para onde havia sido enviado pelo governo gaúcho com o fim de contratar professores e mestres para aquela instituição de ensino. 0 escultor italiano chegou em Porto Alegre ainda em 1909, tornando-se professor do curso de modelagem em arte decorativa da Escola. ${ }^{7}$

Em fevereiro de 1910, já integrado ao corpo docente da Escola de Engenharia e seu Instituto Profissional, Gaudenzi, cumprindo o esperado pelos seus empregadores e pelo PRR, foi com os colegas professores e diretores da instituição, como Pereira Parobé e João Lüderitz, autoridades municipais, estaduais e políticos, engenheiros, construtores, operários e alunos da Escola e do Ginásio Júlio de Castilhos, ao cais do porto de Porto Alegre recepcionar o ex-fundador, diretor e professor da Escola de Engenharia, João Simplício Alves de Carvalho, então deputado federal pelo Rio Grande do Sul, no seu retorno do Rio de Janeiro. Futuramente, Simplício seria o personagem central de uma das capas criadas por Giga para a Kodak, representado como um cavaleiro medieval que defende a instrução pública em uma edição da revista consagrada à Escola de Engenharia. ${ }^{8}$ Em janeiro de 1912, por ocasião de outro retorno de Simplício a Porto Alegre, foi novamente organizada uma recepção pública, ainda mais majestosa que a de 1910, que levou ao porto o corpo docente e discente da Escola de Engenharia, incluindo Gaudenzi. Na ocasião, novamente estiveram presentes os mais importantes polí-

\footnotetext{
${ }^{7}$ Criado em 1906, o Instituto Técnico Profissional foi a mais importante escola de educação elementar e profissional do Rio Grande do Sul. 0 ensino, que era gratuito, destinava-se a filhos de operários e meninos pobres e tinham por fim formar mestres e contramestres para as áreas da construção mecânica e civil, marcenaria e artes gráficas, refletindo a política educacional positivista (LIMA, 2000).

${ }^{8}$ A instituição, que era o orgulho do governo estadual, foi homenageada na edição n. 16 (18/01/1913) da Kodak. Nas suas páginas internas também foram reproduzidos o quadro dos engenheiros civis que concluíram o curso em 1912 e três fotografias dos seus edifícios e institutos.
} 
ticos republicanos vivos. Os mortos e ausentes foram lembrados com brindes.

Nero era o pseudônimo de Orzolino Martins. Em maio de 1908, ele integrava a equipe do semanário humorístico ilustrado Pau Bate, publicado desde abril de 1905 por Astrogildo Barcellos. Em fevereiro de 1910, o Pau-Bate continuava em circulação, mas perdeu o seu diretor artístico, Gregório Nero, provavelmente o pseudônimo usado por Orzolino na época e posteriormente simplificado para Nero. Ao final deste mesmo ano, ele lançou o semanário humorístico e ilustrado 606, cujo nome fora emprestado de um medicamento então em voga, indicado para o tratamento da sífilis. Além de Orzolino, que foi o seu ilustrador e diretor artístico, o semanário também contou com um diretor literário e redator, Henrique Vieira Braga. 0606 teve boa aceitação no meio local, sendo referido pelos diferentes jornais da cidade de forma elogiosa ao longo dos anos. Ele se destacou por suas charges, mas raramente veiculou fotogravuras.

Durante 1911, o 606 continuou sendo publicado e assinalado com elogios em órgãos de imprensa de distintas tendências políticas, tanto os da situação quanto os da oposição, o que significa que distribuía democraticamente as suas críticas políticas. Ele comemorou o seu primeiro aniversário em 28/12/1911 com uma "edição especial e de luxo" de 16 páginas, impressas a cores.

Em setembro de 1912, foi lançada a Kodak. No final de novembro, Braga deixou o 606, que continuou sendo publicado exclusivamente por Orzolino. Essa separação parece ter sido amigável, devendo-se à necessidade de Braga colocar em prática outros planos, como uma peça teatral dramática e uma revista de cunho mais literário. Nero passou a veicular ilustrações na Kodak a partir de fevereiro de 1913, inicialmente anúncios ilustrados e a seguir charges e caricaturas nas páginas internas e nas capas, participando da sua produção durante 1913 e 1914, paralelamente à publicação do 606 . 


\section{Giga e Nero ilustradores}

Giga foi o segundo ilustrador da Kodak e criou o segundo logotipo do nome da revista para a capa, apresentando uma vinheta mais elaborada, leve e movimentada do que a anterior, criada por H. Hübenthal, o primeiro ilustrador. Também criou charges que foram veiculadas no interior da revista para tratar de problemas sociais e costumes, além de anúncios ilustrados, demonstrando grande capacidade técnica e apurado gosto estético.

As charges publicadas nas capas da Kodak eram policromáticas e ocupavam a quase totalidade do espaço. Naquelas que desenhou, Giga abordou a política e temas relativos a comportamento e moral. Ele costumava criar cenas que contavam com a participação de um personagem peculiar, também por ele criado, o Zé Gaúcho, que vestia trajes típicos regionais. Ele estava presente nos acontecimentos, mas às vezes apenas os observava, sem comentá-los; em outras ocasiões, fazia a sua recomendação ou sugestão, dialogava com a personagem central. A primeira aparição de Zé Gaúcho ocorreu na charge veiculada na capa da ed. n. 5 (26/10/1912) e se estendeu por outras dez charges. 0 personagem foi inclusive preservado por Nero nas charges que produziu para as capas quando substituiu Giga, constando em quatro capas (n. 20, 22, 26 e 32).

Atribui-se ao português Rafael Bordalo Pinheiro a primeira representação do Zé Povinho, que teria sido criado em 1882 (FONSECA, 1999, p. 203). Mas a figura já aparece em ilustração de Cândido Aragonês de Faria, no Fígaro porto-alegrense, em 1879 (FERREIRA, 1962, p. 62). 0 fato é que diversas foram as concepções e representações do Zé Povo entre os ilustradores brasileiros desde o século XIX. As capas da revista carioca O Malho, por exemplo, também traziam charges policromáticas de sátira política. Quando o Zé era desenhado por Storni para as capas do semanário, era representado como um tipo popular, que não usava gravata, mas calças com remendos (0 civilista, 2012, p. 150). Já quando desenhado por Lobão para o mesmo O Malho, era repre- 
sentado como um homem comum, um tipo urbano, que se vestia com simplicidade, mas não era pobre. Era uma figura distinta, que usava sapato e chapéu de palhinha, e cuja marca registrada era uma gravada vermelha em laço, que trazia ao pescoço.

Nero produziu duas charges para as capas da Kodak (ed. n. 21 e 24), desenhando um Zé Povo muito semelhante ao de Lobão, exceto pela ausência da gravata vermelha. 0 Zé Gaúcho de Giga, herdado por Nero, não representava o povo, os marginalizados. A charge publicada na ed. n. 21 (08/03/1913) da Kodak, assinada por ele, deixava isso claro ao colocar em cena os dois personagens, o Zé Povo e o Zé Gaúcho.

Segundo Teixeira (2012, p. 52-3), o Zé Povo representava tantos, que ao final não representava ninguém, não passando de um personagem puramente imaginário. Ou representava todos os oprimidos, diante de todos os opressores. Sua singularidade estava em ser mero espectador, externo à sociedade e à lógica das lutas políticas, não mais que um comentador de fatos que não lhe diziam diretamente respeito. Ele seria um observador impotente de uma cena política da qual se sabe e se sente excluído a priori, sempre à margem. Para o autor, ele seria o símbolo do permanente desencontro entre elite e povo, povo e nação, onde um não se reconhece nem se identifica com o outro. Contudo, sua característica central era a lucidez, que o legitimava como comentarista da realidade.

Alguns destes traços podem ser percebidos no Zé Gaúcho, sobretudo a sua posição de observador e comentarista lúcido, mas descomprometido. Diferentemente, ele nunca representou os oprimidos. Acredito que o Zé Gaúcho de Giga tenha sido inspirado no Zé Povo de Lobão, que foi o principal capista d'O Malho entre 1905 e $1914 .^{9}$ 
Em suas charges de sátira política, este personagem foi reincidente, contracenando, em algumas ocasiões, com outra figura de sua criação, o próprio Malho, a representação do periódico. Nele, eles eram parceiros e se apoiavam mutuamente. Giga, que deve ter sido leitor d'O Malho, a mais importante revista de crítica à vida política do país do seu tempo, parece ter partido daquele Zé genérico para criar o seu tipo regional, o Zé Gaúcho, demarcando a sua particularidade também política, como representante gaúcho da federação e cuja participação na política nacional se dava de forma também marginal, ao nível das alianças oligárquicas regionais, externas à política do café-com-leite, em que alternavam-se no poder central os estados de Minas Gerais e São Paulo.

Tanto o Zé Povo de Lobão quanto o Zé Gaúcho de Giga eram observadores, por vezes comentaristas, que aprovavam ou desaprovavam a situação focada. Eles não representavam suas respectivas revistas, o que fica mais explícito no caso d'O Malho, mas pensavam como elas, eram seus aliados (O Civilista, 2012, p. 116). O Zé Povo d'O Malho apoiou a candidatura de Hermes da Fonseca à presidência em 1909, como a revista. 0 Zé Gaúcho da Kodak também avalizou a legitimidade da eleição de Borges de Medeiros ao mandato estadual de 1913-18.

\section{A palheta republicana}

Na sua edição inaugural, a capa da Kodak foi inteiramente ocupada por uma fotografia impressa em cores de um monumento que acabara de ser concluído em uma praça da cidade, mas que não havia ainda sido inaugurado. A princípio, ela estava cumprindo seu programa e mostrando-se atualizada técnica e tematicamente sobre os acontecimentos locais. Mas se formos um pouco mais longe e considerarmos que este monumento era uma encomenda do governo do Estado para glorificar em bronze a memória de Júlio de Castilhos e que ele havia sido construído na principal praça da cidade, a praça Mal. Deodoro (da Matriz), centro dos 
poderes executivo, judiciário e religioso, e que Lourival Cunha, diretor-proprietário da revista, também era correligionário da Federação e militante republicano, o significado da seleção desta imagem como a primeira que o comprador da primeira Kodak veria se modifica.

Para chegar mais perto do sentido que tais práticas e representações podem ter tido para os seus contemporâneos, examinarei quem foi Lourival Cunha e o que fazia antes de editar a Kodak, considerando também o contexto de lançamento da revista.

Lourival Cunha era provavelmente natural de Jaguarão, onde, em outubro de 1907, com cerca de 25 anos, dirigia o jornal republicano A Situação. Nessa função viajou a Porto Alegre algumas vezes, tendo suas visitas notificadas pela Federação. Em março de 1908, inscreveu-se no concurso para 3ํo auxiliar de Instrução Pública e foi aprovado por Jaguarão. No novo cargo, esteve na Capital, visitando o então presidente do Estado, Carlos Barbosa, que era seu conterrâneo. Em abril, por ocasião do seu aniversário natalício, o dirigente recebia cartões de felicitações de correligionários, amigos e interesseiros diversos, sendo seus nomes listados na Federação. Entre 1908 e 1911, o nome de Lourival constou nestas listas e em muitas outras: daqueles que foram ao Palácio do Governo levar felicitações ou pêsames ao presidente do Estado por um aniversário ou morte na família; daqueles que foram aos velórios, missas e sepultamentos de correligionários republicanos; daqueles que foram às recepções, préstitos e despedidas de políticos e autoridades republicanas em suas chegadas e partidas da cidade; daqueles que estiveram presentes em eventos comemorativos à República e à memória de Castilhos; daqueles que festejavam as conquistas técnicas e profissionais do jornal A Federação, órgão oficial do PRR e do governo.

Em junho de 1908, Lourival iniciou sua carreira policial como oficial da Secretaria da Chefatura de Polícia, em Porto Alegre, que era um órgão da polícia judiciária, estadual, e tinha por fun- 
ção a investigação e repressão do crime (MAUCH, 2011). Embora ele fosse um agente interno, acompanhou o delegado de plantão em batidas policiais em terreiros de umbanda, casas de feitiçaria e prostíbulos em 1908, mantendo esta função pública até pelo menos junho de 1913.

Em 1910, Lourival já era casado com a filha de um importante fazendeiro republicano de Jaguarão, que era referido com distinção pela Federação quando visitava a Capital. Em novembro, foi inaugurada a Sociedade Rio-Grandense Protetora dos Animais. Lourival Cunha foi eleito o seu $1^{10}$ secretário e também foi escolhido para compor o seu Conselho Diretor. Entre outros membros do conselho, estava Affonso Hebert, engenheiro, secretário de obras públicas do Estado, republicano e maçon. E construtor do monumento a Júlio de Castilhos.

Até setembro de 1911, Lourival Cunha foi redator do Jornal do Comércio, neste momento alinhado politicamente com A Federação. Neste mês, além de deixar o jornal, também se exonerou do cargo de primeiro secretário da Protetora dos Animais, embora tenha continuado a compor o seu Conselho Diretor.

Em janeiro de 1912, a Brigada Militar (BM), a polícia estadual gaúcha, comemorou o 4ํㅡㅁ aniversário do governo Carlos Barbosa realizando uma festa em sua sede, no Cristal. Carlos Barbosa esteve presente com sua numerosa comitiva, que compreendia secretários de estado, o general Carlos Frederico de Mesquita, o cel. Cypriano Ferreira, comandante da BM, o intendente José Montaury e Lourival Cunha, entre outros. A imprensa esteve representada pelos repórteres dos principais jornais locais: $O \mathrm{Di}$ ário, Correio do Povo, $O$ Independente e A Federação. Todos eles embarcaram no mesmo trem que conduziu o homenageado do centro da cidade até o local, sendo a bordo levantados brindes a Borges de Medeiros e Hermes da Fonseca, militar gaúcho que governava o país desde 1910. Borges também esteve presente no evento, na companhia do deputado federal João Simplício. 
Alguns dias depois, outro acontecimento político significativo envolveu o futuro editor da Kodak e a cúpula do PRR. Foi a partida do senador gaúcho Pinheiro Machado, em passagem pela cidade, para sua terra natal, São Luiz Gonzaga. Uma parte curta do trajeto era feita em vapor. Em Santo Amaro, tomava-se um trem expresso. Pois neste vapor o acompanharam inúmeros republicanos e jornalistas. Lourival Cunha integrava a comissão. A viagem passou entre comes, bebes e discursos: de Borges de Medeiros, de Pinheiro Machado, de João Simplício. Após, o senador seguiu no trem e os convidados retornaram à Capital.

Esta estreita convivência de Lourival com o alto escalão republicano gaúcho no período que precedeu o lançamento da revista seria revertida em uma participação ainda mais direta nas diretrizes do partido a partir de fevereiro de 1912, quando foi fundada a 'Junta Central Popular Pró-Borges', da qual Lourival foi eleito secretário geral. Tratava-se de um órgão de propaganda política, que reunia a "mocidade castilhista" e cujo objetivo era fazer a propaganda organizada da candidatura de Borges de Medeiros à presidência do Estado. Durante o ano, nos eventos (missas, velórios, recepções) de que participou, nas listas em que constou, Lourival apareceu como representante da Junta.

Em 28 de setembro, foi publicado o primeiro número da Kodak, com direção de Lourival Cunha, redação de Mansueto Bernardi ${ }^{10}$ e colaboração de Victor Silva, Zeferino Brasil, Homero Prates, João Pinto da Silva, Vieira Pires, Maurício Cardoso ${ }^{11}$ e vários ou-

\footnotetext{
${ }^{10}$ Em 1909, após atuar no interior do estado como professor primário, Bernardi tornou-se funcionário público estadual, ingressando no Tesouro do Estado, órgão em que progrediu sucessivamente, assumindo importantes chefias a partir de 1914. Ele redigiu a Kodak por três meses, atuando simultaneamente na redação do Correio do Povo. Ao deixar a revista, foi substituído pelo poeta e jornalista Augusto Carvalho, que será o chefe de redação da Kodak até novembro de 1913, retomando a função em abril de 1914 e nela permanecendo até a interrupção da publicação.

${ }^{11}$ Deputado estadual republicano, que assumiria a direção de redação do jornal A Noite, lançado por Lourival Cunha em janeiro de 1914.
} 
tros, entre os quais muitos militares. 0 seu repórter fotográfico era o foto-cinegrafista carioca Emílio Guimarães. ${ }^{12}$ Fig. 1

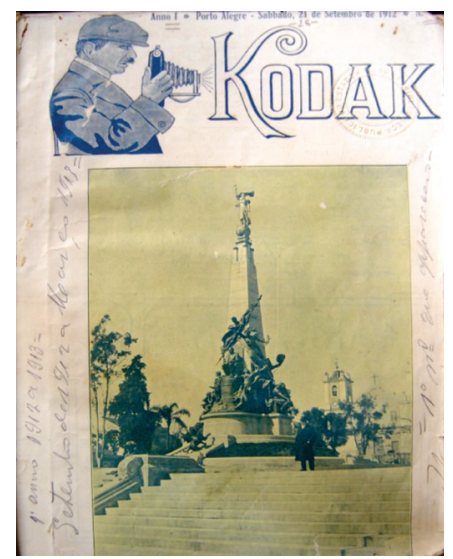

Fig. 1 - Kodak, Porto Alegre, ano 1, n. 1, 28/09/1912.

Capa - Fotografia

A revista surge, portanto, em pleno ano eleitoral, às vésperas da eleição, que seria realizada em 25 de outubro, com Lourival fazendo a campanha de Borges, como se sabe. 0 monumento a Júlio de Castilhos, cuja construção foi decidida logo após a sua morte (24/10/1903), já estava concluído. ${ }^{13}$ As últimas peças haviam chegado da Europa e sido colocadas em seus lugares no final de agosto, cogitando-se, na época, inaugurá-lo no feriado de 20 de setembro, data histórica fundadora para os republicanos

\footnotetext{
${ }^{12}$ Emílio vivia em Porto Alegre desde maio de 1911. No segundo semestre de 1912, contratado pelo cinema Recreio Ideal, produziu o primeiro cinejornal porto-alegrense, exibido semanalmente naquele cinema. Em fevereiro de 1913, ele se tornou o diretor artístico da revista e, em agosto, sócio de Lourival, ou seja, um dos proprietários. Nessas funções permaneceu até abril de 1914, quando deixou Porto Alegre e foi para a Guerra do Contestado filmá-la e fotografá-la para a Kodak e o jornal $A$ Noite (TRUSZ, 2011).

${ }^{13} \mathrm{O}$ monumento a Júlio de Castilhos foi encomendado ao escultor Décio Villares e decidiu-se elevá-lo na da região central da praça Mal. Deodoro. A praça foi cercada ainda em junho de 1910, mas sua pedra fundamental só foi assentada em setembro. A construção foi dirigida pelo engenheiro Affonso Hebert e fiscalizada pelo secretário das obras públicas, Cândido Godoy.
} 
gaúchos, comemorativa à Revolução Farroupilha. A seguir, decidiu-se pela sua inauguração no feriado de 15 de novembro, data histórica nacional, comemorativa à Proclamação da República. Mas essa ideia também foi abandonada, alegando-se necessidade de obras complementares de embelezamento do logradouro. A essa altura, Borges já havia sido eleito o novo presidente do Estado, devendo tomar posse em 25 de janeiro do ano seguinte. Pois foi neste dia que se deu a inauguração oficial do monumento, com direito à presença do senador Pinheiro Machado, vindo do RJ para prestigiar os chefes republicanos gaúchos do presente e do passado, Borges e Castilhos, este que "ficaria perpetuado no bronze, ditando lições de civismo às gerações do porvir." (Jornal do Comércio, 11/09/1910, p. 5). Considerando-se tais dados, é possível perceber a veiculação da fotografia do monumento a Castilhos na capa da Kodak n. 1 também como uma declaração de opção política, uma declaração de voto, e um instrumento de propaganda pró-Borges.

\section{Política estadual}

As homenagens ao poder estadual e aos republicanos também se espalharam pelas páginas da primeira edição da Kodak na forma de retratos fotográficos, marcando presença os do então presidente do Estado, Carlos Barbosa, e do seu futuro substituto, Borges de Medeiros, então candidato à eleição, além de Protásio Alves, secretário do Interior e do Exterior de ambos. A partir da $2^{\underline{a}}$ edição, foram publicadas fotografias das obras do governo estadual. Nas edições n. 2 (05/10/1912) e n. 5 (26/10/1912), o foco recaiu sobre o Palácio Piratini, cuja construção, iniciada em 1896 e paralisada em 1901, foi retomada por Carlos Barbosa em 1910, tendo sido um dos projetos mais problemáticos dos republicanos (DOBERSTEIN, 1992, p. 35).

Nas edições n. 3 (12/10/1912) e n. 13 (21/12/1912) foram reproduzidas novas fotografias do monumento a Castilhos. A pri- 
meira delas o enquadrava na praça, em perspectiva mais ampla que a da foto da capa n. 1, observando-se que ambas foram produzidas em agosto de 1912, antes da conclusão das obras. Na ed. n. 13, saíram quatro fotografias, registrando diferentes estágios da sua construção. Nelas posam operários e o engenheiro construtor, Affonso Hebert, constando ainda os andaimes e guindastes utilizados para erguer pedras e peças de bronze. Registra-se o assentamento das primeiras pedras da base, passando pela construção da pirâmide e colocação das estátuas, até a retirada dos tapumes.

Se a preocupação em documentar o processo deve-se ao engenheiro (ele assina e data as fotos), a divulgação desta coleção seqüencial de imagens, coroada com uma sétima fotografia, do evento da inauguração, publicada na ed. n. 20 (01/03/1913), corresponde, primeiramente, aos objetivos da revista como veículo de ponta da imprensa ilustrada, que dessa forma proporciona aos seus leitores uma nova modalidade de apreensão visual da realidade cotidiana. Com a publicação dessas imagens, de forte caráter informativo e documental, a revista dá visibilidade a um processo que esteve oculto da população enquanto se desenvolveu. Em segundo lugar, corresponde às expectativas da sua comunidade leitora, a elite econômica, política e intelectual que tais obras também representavam, promoviam e legitimavam, distinção que é potencializada a partir do momento que a revista, como veículo de comunicação, amplia a circulação das fotografias e, ao mesmo tempo, as torna colecionáveis.

Falando em coleção, a edição n. 7 (09/11/1912) também se destaca por ter oferecido aos leitores acesso a uma fotografia identificada pela própria revista como "Um quadro histórico", verdadeiro documento do processo de instauração da República no país. Trata-se de um retrato de grupo, reunindo homens, mulheres e crianças, que posam dentro de uma embarcação. Segundo a legenda, são os passageiros do vapor Camillo, que seguia para o Rio de Janeiro, conduzindo representantes gaúchos à Consti- 
tuinte Republicana de 1890. Entre eles estavam os jovens Júlio de Castilhos, Borges de Medeiros, Ramiro Barcellos e Fernando Abott, entre outros.

Considerando-se ainda as representações produzidas e veiculadas pela Kodak acerca da política estadual, destacam-se as charges criadas por Giga para as capas das edições n. 9 e n. 17, por sua alusão à eleição e posse de Borges de Medeiros ao seu terceiro mandato como presidente do Estado. ${ }^{14}$ Na charge da ed. n. 9 (23/11/1912), um homem gigante, alto e forte, já grisalho e bem vestido, que representa o PRR, concentra as atenções. Ele ergue Borges de Medeiros com uma das mãos. Na outra, sustenta a cadeira da presidência. Zé Gaúcho observa a cena, desenhado na mesma escala reduzida de Borges e da cadeira. Ele desempenha uma função mista de espectador e padrinho conselheiro. Fig. 2

Borges acabara de vencer as eleições para o governo do Estado. Na representação, ele, que é elevado às alturas pelo partido, segura uma balança, o símbolo da justiça, enfatizando que sua vitória era legal, constitucional, além de estar respaldada em sólida base política. Assim eram contestadas as acusações da oposição sobre as fraudes eleitorais e o abuso de poder, que de fato caracterizavam as eleições no Estado. As frases transcritas na base da imagem como falas de Borges e Zé Gaúcho enfatizam essa interpretação, evidenciando a opção política de Zé Gaúcho e o seu aval aos resultados da eleição. Respondendo ao PRR, que diz a Borges: “- Equilibre-se nessa posição, seu chefe!... olhe que em tal altura nem todos se agüentam!..., ele diz: "Nada de posição. Aqui não há disso. 'Quem está montado na razão, não precisa de esporas.'”

14 Tendo ocupado o cargo por dois mandatos consecutivos (de cinco anos) entre 1898 e 1908, Borges retornou à administração direta do Rio Grande do Sul em 1913, permanecendo no poder até 1928, quando foi substituído por Getulio Vargas. Essa perenidade, assegurada pela Constituição Estadual de 1891, pelo voto em aberto e por fraudes eleitorais, teve a sua contestação mais aguda na guerra civil de 1923. 0 movimento, que exigia o fim da "ditadura" borgista, só foi pacificado após intervenção do governo federal e garantias de mudança constitucional. 
Numa homenagem de caráter mais oficial ao recém eleito, também foi publicado no interior da revista o seu retrato.

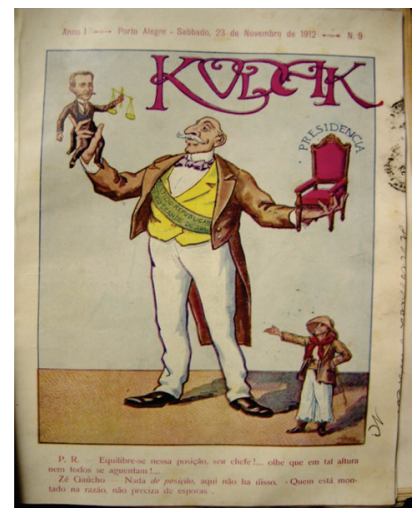

Fig. 2 - Kodak, Porto Alegre, ano 1, n. 9, 23/11/1912.

Capa - Charge - Autor: Giga

A charge da capa da ed. n. 17 (25/01/1913) retoma a questão da legitimidade da eleição de Borges, mas desta vez aludindo a sua posse. Tal edição é publicada justamente nesse dia, que também foi o da inauguração do monumento a Júlio de Castilhos. Na cena, Borges, trajando gala, toma o caminho do tapete vermelho que leva à cadeira presidencial, em cujo encosto estão gravados os símbolos da república rio-grandense. A figura gigantesca de Júlio de Castilhos paira por trás da cadeira como um espectro e a oferece a Borges. A imagem reafirma a ideia de que o "Grande Morto" continuava presente, orientando, protegendo e avalizando a atuação do seu discípulo e sucessor. Ao comentário de Borges: “- Olha Zé, ao sentar-me novamente nesta cadeira, tenho na frente a visão querida do mestre.", responde Zé Gaúcho, coroando a cena com a reprodução da máxima positivista: “- É a confirmação da sentença do grande filósofo, dr: - 'os vivos são cada vez mais governados pelos mortos'”' Ele se refere a Augusto Comte e aos seus princípios, que inspiraram Júlio de Castilhos na elaboração de doutrina política positivista. Trata-se de dar nova expressão à insistente evocação da figura de Castilhos 
pelos borgistas, uma figura política menos disponível a críticas, pois glorificada, como justificativa para legitimar Borges como seu herdeiro político legítimo.

\section{Política municipal}

Diferente do que aconteceu com os representantes da política estadual, o "eterno intendente" (BAKOS, 1996) Montaury e sua administração foram objeto de críticas sucessivas em charges veiculadas na capa e nas páginas interiores da Kodak, bem como em crônicas. 0 engenheiro carioca José Montaury administrou Porto Alegre entre 1897 e 1923 rigidamente dentro dos preceitos positivistas, que primavam pelo lema "conservar, melhorando" e orientavam-se pela necessidade de manter o equilíbrio orçamentário. Em seu governo, empreendeu medidas no sentido de melhorar o sistema urbano, qualificando serviços de abastecimento de água e esgotos, regulamentando o transporte coletivo e estabelecendo novas linhas férreas, operando obras de escoamento de águas pluviais, pavimentação de antigos largos e criação e arborização de praças. Mas foram obras morosas e comedidas, de pouca visibilidade.

Por outro lado, era um republicano, membro do PRR e figura de confiança do governo do Estado na condução da Capital. Assim, as críticas e ironias a sua administração misturavam-se ao respeito pela pessoa do intendente e pelo poder que lhe era atribuído a cada reeleição, resultando em um tratamento quase infantilizado de sua figura, tratada comumente como inofensiva, incapaz de reagir com autonomia, uma espécie de marionete. Paradoxalmente, evitava-se relacioná-lo ao poder estadual, que era o responsável por sua manutenção no poder e, até certo ponto, por suas iniciativas ou pela falta delas.

Assim, o seu retrato oficial foi publicado com certa solenidade na ed. n. 2 da revista. A 4⿳a edição (19/10/1912) trouxe o retrato dos conselheiros municipais, na ocasião em que foram empossa- 
dos, junto com o intendente, em 15/10. Eles eram eleitos entre os capitalistas influentes da cidade e votavam o orçamento do $\mathrm{Mu}$ nicípio. Já a capa da edição n. 20 (01/03/1913) traz uma charge primorosa de Giga, que ilustra bem o que foi dito acima. Fig. 3

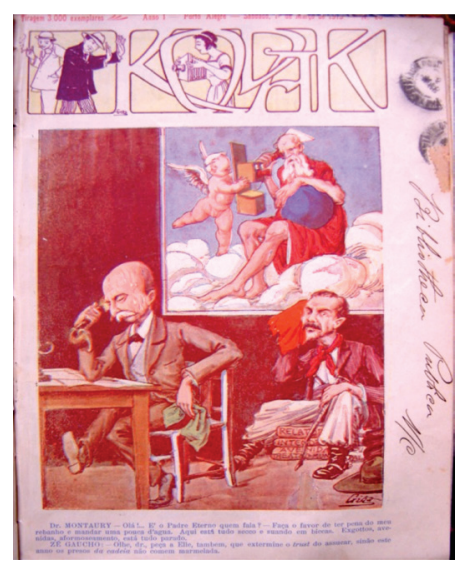

Fig. 3 - Kodak, Porto Alegre, ano 1, n. 20, 01/03/1913.

Capa - Charge - Autor: Giga

Na cena, que se passa no interior do gabinete do Intendente, Zé Gaúcho, que está sentado em uma pilha de documentos municipais, como o relatório e projetos de obras públicas, e sofrendo com o forte calor, acompanha o drama do administrador local, que recorre a Deus por telefone, pedindo chuva e reclamando que a seca era a causa da interrupção dos projetos de melhoramento urbano de sua administração: "- Esgoto, avenidas, aformoseamento, está tudo parado.” Zé está justamente sentado sobre estes projetos, de modo que a própria imagem expressa a sua perda de utilidade e função: de documentos, vetores de obras, tornaram-se assento. A ideia da piada é que a resolução dos problemas municipais dependia de uma preocupação maior do divino com a capital gaúcha. Zé aproveita a ligação e sugere que o intendente também peça aos céus o fim do truste sobre o açúcar. 
Na ed. n. 32 (24/05/1913), dando nova amostra da percepção corrente sobre Montaury, foi publicada uma charge de Nero representando-o a cavalgar uma tartaruga, em cuja casca lia-se: "Melhoramentos de Porto Alegre". Seu título era "Locomoção rápida". Zé Gaúcho passa a cavalo, o cumprimenta com o chapéu e observa que, nesse ritmo, não chegaria nunca ao destino. Já o intendente retruca, respondendo que devagar se vai longe e é mais seguro. Zé o critica, recomendando pressa.

\section{Política nacional}

A primeira referênciaà política nacional nas capas da Kodak teve lugar na ilustração alegórica criada por Giga para a ed. n. 8 (16/11/1912), expressando uma visão otimista sobre a República, convulsionada então por sucessivos movimentos sociais, duramente reprimidos pelo marechal Hermes da Fonseca durante o seu autoritário governo. Neste caso, uma mulher, representando a República brasileira, em pose altiva e resoluta, segura a bandeira do Brasil com uma mão e, com a outra, dirige uma biga romana puxada por dois cavalos brancos. Na base há uma trova em verso, que remete à Guerra do Contestado: "Apesar, afirma o Giga, dos fanáticos do monge, levada por esta biga, a República há de ir longe.... Iniciada em outubro de 1912, no território dito do Contestado, pois disputado pelos estados de Santa Catarina e Paraná, a guerra opôs forças do governo federal e estadual aos sertanejos que viviam na região e que foram inicialmente liderados por um monge, sendo por isso estigmatizados pela opinião pública como "fanáticos". ${ }^{15}$ É a eles que a trova se refere.

Já a política nacional foi objeto de crítica e ironia na Kodak, sendo o presidente Hermes da Fonseca, embora gaúcho e apoiado

\footnotetext{
${ }^{15}$ Essa população, composta de nativos e grupos egressos de diferentes estados, enfrentava seculares problemas sociais, agravados pelo desemprego, pela exploração e expropriação de terras, decorrentes da aliança firmada entre o governo brasileiro e empresas estrangeiras do ramo ferroviário e madeireiro. O conflito se estendeu por quatro anos, até 1916, e estima-se que tenha deixado mais de 10 mil mortos.
} 
pelo Rio Grande do Sul na campanha eleitoral de 1909, objeto de riso e de crítica. Pinheiro Machado foi outra figura marcante nas charges. Ele foi, talvez, o político mais assíduo nas ilustrações humorísticas brasileiras do período. Porém, a sua atuação na sustentação do governo de Hermes, que motivou contundentes reações na imprensa da Capital Federal, foi percebida no meio local com certo orgulho. Enquanto que no Rio de Janeiro Pinheiro era conhecido como o Chantecler, o galo dos terreiros, no Rio Grande do Sul foi chamado de Napoleão dos Pampas.

Pinheiro Machado foi um dos republicanos históricos que lançaram a candidatura do militar Hermes da Fonseca à presidência da República em 1909, contra o civilista Rui Barbosa. As eleições acontecem em 01/03/1910 e Hermes venceu Rui, assumindo o governo em 15/11 e tendo por vice Venceslau Brás. A maior influência de Pinheiro Machado na direção da política nacional se deu a partir daí. Em outubro de 1910, ele lançou o Partido Republicano Conservador (PRC), procurando organizar uma agremiação de âmbito nacional (todos os demais partidos eram regionais) que reunisse os apoiadores de Hermes com o objetivo de melhor controlar a política nacional.

O controle dos estados por caciques políticos era a regra. Bem como as lutas entre eles pela manutenção deste domínio. 0 programa de governo de Hermes prometia substituir a política dos governadores pelo centralismo, tornando o governo independente das oligarquias. A partir de 1911, é acionada com tal fim a política salvacionista, que consistia em depor governadores nos Estados e os substituir por interventores fiéis ao governo. Marcadas por forte autoritarismo, tais intervenções provocaram resistência e conflitos armados, bem como reações no Congresso, no Senado e na imprensa.

Essa política, que foi utilizada pelo senador Pinheiro Machado como campo de manobras políticas, permitiu que ele estabelecesse alianças entre o RS e estados do norte e nordeste, apoian- 
do e manobrando coronéis. Por isso, Pinheiro e Hermes foram os alvos preferidos dos humoristas ilustradores brasileiros durante o período $1910-14$, sendo o primeiro percebido como o presidente de fato, aquele que realmente governava no lugar do eleito. Esse poder lhe amealhou admiradores e inimigos.

A atuação do senador gaúcho e seus conchavos políticos em nível nacional foram criticados na charge criada por Giga para a capa da ed. n. 11 (07/12/1912) da Kodak. Protagonizada por Pinheiro Machado, a cena o mostra sentado a uma mesa cheia de correspondências e preenchendo-as com os nomes de seus destinatários. É possível identificar alguns deles, como o general Mena Barreto, Lauro Sodré e Rui Barbosa. No chão há várias outras cartas, bem como livros com a sigla do PCR gravada na capa. Zé Gaúcho observa a situação e faz uma advertência ao senador, apontando-lhe o dedo, mas o conselho é recebido com expressão de tédio. A ilustração foi inspirada em um telegrama veiculado no Correio do Povo, que questionava tal prática.

Pinheiro reaparecerá em mais duas charges de Giga, veiculadas nas capas das edições n. 18 e n. 22, a primeira aludindo à sustentação política do presidente da República pelo senador e a segunda ao controle que exercia ou procurava exercer sobre as oligarquias regionais por meio de manobras políticas e alianças. Desde 1909, os ilustradores de revistas cariocas como Careta e Fon-Fon se esmeravam na representação humorística de Pinheiro Machado como criador e manipulador de Hermes. Em uma charge criada por J. Carlos para a Careta em outubro de 1909, representa-se um atelier de escultura, no interior do qual o escultor, Pinheiro Machado, olha sério para a sua criação, uma pequena estatueta sobre um pedestal, representando Hermes, e lhe diz, de dedo em riste e com um martelo em uma das mãos, como a ameaçá-la de destruição, que "não fale". A ilustração faz referência a Pinóquio, que ganhou vida própria e desobedeceu ao pai (O Civilista, 2012, p. 127). Outro exemplo é a charge desenhada por K. Listo para a Fon-Fon em agosto de 1910, que repre- 
senta Pinheiro Machado com uma babá que segura uma mamadeira e empurra um bebê no andador. 0 bebê, claro, é Hermes. Na mamadeira lê-se "conselhos". (O Civilista, 2012, p. 130).

A charge criada por Giga para a ed. n. 18 (15/02/1913) da Kodak também é memorável. Trata-se de uma cena de banho de mar, em que Pinheiro segura Hermes para que não afunde, ajudando- o a boiar ao sabor das ondulações. Fig. 4

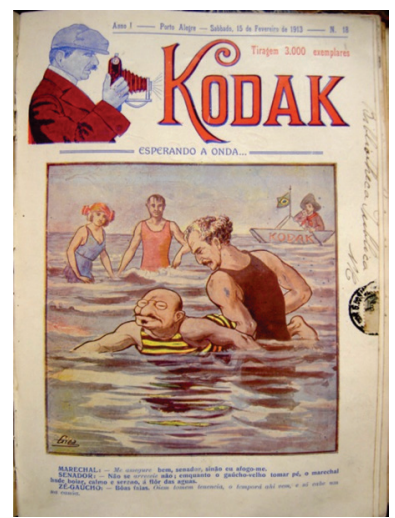

Fig. 4 - Kodak, Porto Alegre, ano 1, n. 18, 15/02/1913.

Capa - Charge - Autor: Giga

A profundidade é rasa e mesmo assim Hermes não consegue ficar em pé sozinho: clama pela ajuda de Pinheiro porque tem medo de se afogar. 0 senador o tranqüiliza, dizendo que, enquanto continuar na posição que ocupa, o marechal há de boiar em segurança. Ao fundo, Zé Gaúcho observa a cena, remando em uma canoa da Kodak, onde tremula uma bandeira brasileira. Zé comenta o diálogo dos políticos, avisando sobre a previsão de temporal, já que sua canoa só poderia salvar um dos dois.

Para a capa do n. 22 (15/03/1913), Giga criou uma charge representando Pinheiro Machado, agachado, esforçando-se para segurar os fios de vários balões coloridos representando polí- 
ticos. Eles tentam escapar e ele procura mantê-los, reclamando do seu "peso". Zé Gaúcho observa a cena, mas não se compromete. Segundo Mauch (1994, p. 50), a manipulação realizada pelo senador no processo político eleitoral da época, abordada na ilustração, devia-se ao cargo por ele ocupado no Senado, que lhe permitia "controlar a Comissão de Verificação de Poderes, responsável pela diplomação ou 'degola' dos candidatos eleitos, prática que se constituía no elemento-chave da política dos governadores."

Em 29/03/1913, uma crítica mais contundente a Hermes seria publicada na revista, que se alinha aos colegas de classe, os veículos de imprensa cariocas, para condenar o autoritarismo do marechal. Nero ilustra a capa da ed. n. 24 com uma charge onde uma mulher com uma pena, representando a imprensa, e um homem identificado como Zé, representando o cidadão urbano carioca comum, são envolvidos em uma nuvem de fumaça ou poeira, que representa a ira de Hermes, figura gigantesca que surge ao alto, de punho fechado e aspecto raivoso. Segundo o texto agregado, a ilustração foi inspirada em um telegrama enviado da Capital Federal para os jornais porto-alegrenses, informando que o presidente pretendia censurar a imprensa carioca em razão das charges e caricaturas que o vinham criticando.

O governo de Hermes cresceu em impopularidade ao longo dos anos. Em 1913, o país estava em crise, que repercutiu sobre a sucessão presidencial. Pinheiro Machado tentou se candidatar pelo PRC, mas o seu nome foi vetado por uma coligação formada por São Paulo e Minas Gerais, apoiados por Pernambuco e Rio de Janeiro. Em 17/05/1913, quando a questão ainda estava em aberto, saiu na capa da ed. n. 32 da Kodak uma charge de Nero intitulada "A tentação". Na cena, um homem vestindo traje franciscano e ajoelhado em frente a uma cruz, instalada no altar de uma rocha, é tentado por uma figura de mulher seminua. Ela sai de um livro em fogo e é identificada como "candidatura". Ele é Pinheiro Machado. 
A partir de 24/05/1913, não são mais publicadas charges de sátira política nas capas da Kodak. Os políticos, porém, continuarão se fazendo presentes neste espaço, representados ora por meio de caricaturas, ora de fotografias. Nesse sentido, são contemplados Hermes da Fonseca, Borges de Medeiros, Pinheiro Machado, Venceslau Braz e até o líder federalista Gaspar Silveira Martins.

\section{Considerações finais}

A partir das colocações reunidas neste estudo inicial, acredita-se terem sido evidenciadas algumas das relações nas quais estavam inscritos os produtores da revista Kodak, bem como os compromissos políticos que em algum grau orientaram as temáticas reunidas na revista e as formas como foram abordadas.

Trata-se de fazer emergir o diálogo entre a revista e a sociedade e o papel da imprensa na expressão, dinamização e construção da realidade.

Além da militância política do seu diretor, a presença das 'cores políticas' na publicação também se explica por ter sido de praxe em vários outros periódicos nacionais do gênero, nos quais a política marcou presença, ganhando fluência sob a expressão mais coloquial, lúdica e libertária da ilustração de humor. 0 interesse pela política também esteve perpassado pela atenção às práticas oficiais e mundanas da elite local, da qual os governantes e políticos faziam parte e entre a qual a Kodak buscava ser bem aceita. Esse bom relacionamento alimentava e era alimentado pelo interesse do grupo dominante em se ver representado em suas páginas. Assim, a revista correspondia às expectativas dessa parcela da população por visibilidade, distinção e legitimação sociais. As notas da imprensa local sobre as edições também permitem observar que ela alcançou o seu objetivo como revista ilustrada, tornando-se motivo de orgulho como produto cultural, sendo equiparada com louvor às publicações congêneres cariocas e colocando a capital gaúcha no mapa da modernidade. 


\section{Fontes}

Kodak (revista), Porto Alegre, 1912 a 1914

606 (revista), Porto Alegre, 1911

O Diário (jornal), Porto Alegre, 1911 a 1913

A Federação (jornal), Porto Alegre, 1908 a 1914

Correio do Povo (jornal), Porto Alegre, 1910 a 1914

O Independente (jornal), Porto Alegre, 1908 a 1911, 1914

Jornal do Comércio (jornal), Porto Alegre, 1908, 1910

Folha do Sul (jornal), Porto Alegre, 1910

A Reforma (jornal), Porto Alegre, 1911

\section{Referências bibliográficas}

AXT, Gunter. Apontamentos sobre o sistema castilhista-borgista de relações de poder. In.: Júlio de Castilhos e o paradoxo republicano. Org. Gunter Axt [et al.]. Porto Alegre: Nova Prova, 2005.

BACZKO, Bronislaw. Imaginação social. In: Enciclopédia Einaudi. Vol.1. Memória e História. Lisboa: Imprensa Nacional e Casa da Moeda, 1984.

BAKOS, Margaret M. Porto Alegre e seus eternos intendentes. Porto Alegre, EDIPUCRS, 1996.

BRITO BROCA. A vida literária no Brasil - 1900. Rio de Janeiro: MEC/Serviço de documentação, 1958.

CHARTIER, Roger. 0 mundo como representação. Estudos Avançados, São Paulo, no 11 (5), p. 173-191, 1991.

CORONA, Fernando. Cem Anos de Formas Plásticas e seus Autores. In.: BECKER, KLAUS (Org.). Enciclopédia Rio-Grandense. 2ovolume. 0 Rio Grande antigo. Canoas: Regional, 1956.

DOBERSTEIN, Arnoldo W. Porto Alegre. 1900-1920: estatuária e ideologia. Porto Alegre: Secretaria Municipal da Cultura, 1992.

DUARTE, Luiz A. F. Comunicação: imprensa e poder no Brasil republicano: estudo interpretativo das relações dos jornais A Federação, Correio 
da Manhã, Correio do Povo e Tribuna da Imprensa com os políticos José Gomes Pinheiro Machado, Getúlio Dornelles Vargas e Artur da Costa e Silva. 2012. 456 f. Tese (Doutorado em Comunicação Social) - Faculdade de Comunicação Social, PUCRS, Porto Alegre.

FERREIRA, Athos D. Imprensa caricata no Rio Grande do Sul no século XIX. Porto Alegre: Globo, 1962.

FONSECA, Joaquim da. Caricatura. A Imagem gráfica do humor. Porto Alegre: Artes \& Ofícios, 1999.

FRANCO, Sérgio da C. O Partido federalista. In.: História geral do Rio Grande do Sul. Vol. 3. Tomo 1. República Velha (1889-1930). RECKZIEGEL, Ana L.S. e AXT, Gunter (Direção). Passo Fundo: Méritos, 2007.

HEINZ, Flavio M. Positivistas e republicanos: os professores da Escola de Engenharia de Porto Alegre entre a atividade política e a administração pública (1896-1930). Revista Brasileira de História. São Paulo, v. 29, n. 58, p. 263289, 2009.

LEVI, Giovanni. Sobre a micro-história. In.: BURKE, Peter. (Org.). A escrita da história. São Paulo: UNESP, 1992.

LIMA, Raquel R. Liceu Parobé: um instituto das artes e ofícios. Arqtexto, Porto Alegre, n. 0, p.74-84, 2000.

MARTINS, Ana L. Desenho, letra e humor. Estereótipos na caricatura do Império. In.: LUSTOSA, Isabel (Org.). Imprensa, humor e caricatura. A questão dos estereótipos culturais. Belo Horizonte: Editora UFMG, 2011.

MAUCH, Cláudia. Dizendo-se autoridade: polícia e policiais em Porto Alegre, 1896-1929. 2011. 282 f. Tese (Doutorado em História) - Instituto de Filosofia e Ciências Humanas, Universidade Federal do Rio Grande do Sul, Porto Alegre.

MENEZES, Ulpiano T. B. de. Fontes visuais, cultura visual, História visual. Balanço provisório, propostas cautelares. Revista Brasileira de História, São Paulo, v. 23, n. 45, pp. 11-36, 2003.

NOGUEIRA, Clara A. Revista Careta (1908--1922): símbolo da modernização da imprensa no século XX. Miscelânea, Assis, v.8, p. 60-80, jul./dez. 2010.

o Civilista. Rui Barbosa no imaginário político dos chargistas brasileiros. TEIXEIRA, l.G.S; RIBEIRO, P.K. e TELLES, M.S. (Org.). Rio de Janeiro: Fundação Casa de Rui Barbosa, 2012.

PESAVENTO, Sandra J. História do Rio Grande do Sul. Porto Alegre: Mercado Aberto, 1990. 
Porto Alegre Caricata: a imagem conta a história. PESAVENTO, Sandra (org.). Porto Alegre: Unidade Editorial da Secretaria Municipal da Cultura da PMPA, 1994.

REDE, Marcelo. História e cultura material. In.: CARDOSO, Ciro Flamarion e VAINFAS, Ronaldo (orgs.). Novos domínios da história. Rio de Janeiro: Elsevier, 2012.

RIBEIRO, Pedro K. Memórias de Zé Povo ou memórias individuais? 0 povo na retórica da charge e a legitimação dos discursos políticos dos caricaturistas na imprensa carioca do início do século XX. XIV Encontro regional da Anpuh (Anais) - Rio de Janeiro, UniRio, 2010.

SALIBA, Elias T. Raízes do riso. A representação humorística na história brasileira: da Belle Époque aos primeiros tempos do rádio. São Paulo: Companhia das Letras, 2002.

SILVA, Marcos A. da. Rir do despoder. Zé Povo em Fon-Fon. Projeto História, São Paulo, v. 8/9, p. 27-40, 1992.

TEIXEIRA, Luiz G. S. 0 traço como texto: a história da charge no Rio de Janeiro de 1860 a 1930. Rio de Janeiro: Fundação Casa de Rui Barbosa, 2001.

TRINDADE, Hélgio. Aspectos políticos do sistema partidário republicano rio-grandense (1882-1937). In: Rio Grande do Sul: Economia e política. DACANAL, José H. e GONZAGA, Sérgius (Org.). Porto Alegre: Mercado Aberto, 1979.

TRINDADE, Hélgio. Rio Grande da América do Sul: partidos e eleições (18231990) Porto Alegre: Editoria da Universidade/UFRGS/ Sulina, 1991.

TRUSZ, Alice D. A publicidade nas revistas ilustradas: o informativo cotidiano da modernidade. Porto Alegre. Anos 1920. 2002. 266 f. Dissertação (Mestrado em História) - Instituto de Filosofia e Ciências Humanas, UFRGS, Porto Alegre.

TRUSZ, Alice D. Os usos das imagens na construção das práticas culturais: as fotogravuras do público do cinema na revista Kodak. In.: Imagens. Arte e Cultura. SANTOS, Alexandre R. e CARVALHO, Ana A. (Orgs.) Porto Alegre: Editora da UFRGS, 2012.

TRUSZ, Alice D. Emílio Guimarães: as múltiplas identidades de um produtor de imagens no Brasil dos anos de 1910. Significação, São Paulo, n. 36 (2), 2011. Disponível em: < http://www.usp.br/significacao/atual.asp> Acesso em: 19 jan 2013.

ZUBARAN, Maria A. 0 mundo virado de ponta cabeça: inversão simbólica e resistência cultural na caricatura porto-alegrense do século XIX. Anos 90, Porto Alegre, vol. 8, n. 14, p. 80-94, dez, 2000.

Recebido em 01.11. 2013.

Aprovado em 30.11.2013. 